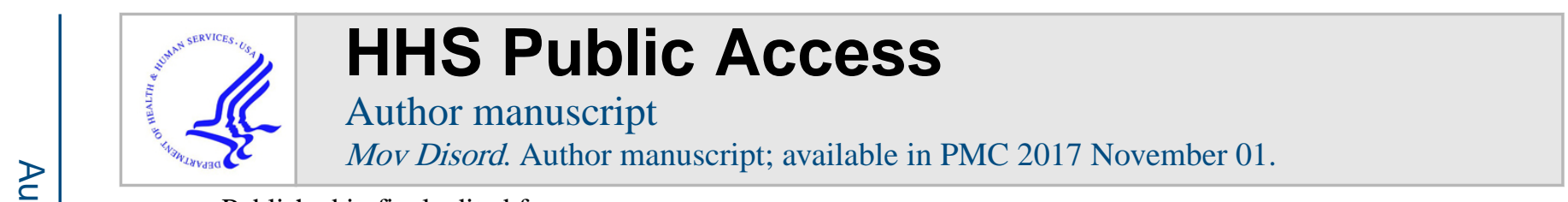

Published in final edited form as:

Mov Disord. 2016 November ; 31(11): 1759-1760. doi:10.1002/mds.26765.

\title{
Locus Pocus
}

\section{H. A. Jinnah, M.D., Ph.D. \\ Departments of Neurology, Human Genetics \& Pediatrics Emory University School of Medicine Atlanta GA, 30322}

\begin{abstract}
The International Parkinson Disease and Movement Disorders Task Force for Nomenclature of Genetic Movement Disorders recently proposed a new approach for nomenclature. ${ }^{1}$ The traditional approach has numerous problems, and the task force should be congratulated for trying to fix them. The new approach is markedly different from the existing one. Like a good magician, the task force has put a bunch of ugly rats into a hat, and pulled out a beautiful bird. The task force pointed out some of the weaknesses of the new plan, but its logic reveals some further problems.

In the proposed plan, assigning a prefix (DYT, PARK, SCA, etc...) requires that the phenotype be a prominent feature in the majority of cases. What is prominent or a majority is subject to debate. For example, Lesch-Nyhan disease was conferred DYT/CHOR-HPRT1, to emphasize the prominence of dystonia and chorea. However, chorea is not usually prominent, and does not occur in the majority. ${ }^{2,3}$ Spasticity is nearly as prominent as chorea, so why not add HSP to make DYT/CHOR/HSP-HPRT1? Another example is myoclonus-dystonia, designated DYT-SCGE to emphasize the dystonia. Dystonia is often minor or absent, yet myoclonus is universal. ${ }^{4,5}$ So why not MYOC-SCGE, or MYOC/DYT$S C G E$ ? Also, there currently is no prefix for tremor. Once tremor genes are delineated and a TREM prefix is created, will we need to add TREM to many existing disorders including PARK, DYT, and SCA?
\end{abstract}

The proposed plan also permits a prefix only after confirmation by two independent groups. For rare disorders, most reports are initially based on very small cohorts. The discovery of a genetic defect almost invariably leads to appreciation of a broader phenotype, or alternative phenotypes that are quite distinct. What if two groups do not agree? This means the prefix will be subject to frequent change, and frequent dispute.

The proposed plan also assigns a prefix based exclusively on the movement disorder, overlooking other phenotypic features, which are sometimes more important. For example, all patients with Lesch-Nyhan disease have severe self-injurious behavior, cognitive disability and overproduction of uric acid. For myoclonus-dystonia, psychiatric features are

\footnotetext{
Financial disclosures related to the manuscript

There are no relevant financial disclosures related to this letter.

Conflicts of interest

The corresponding author does not like magicians.

Author contributions

H. A. Jinnah drafted and revised the letter.
} 
prominent and frequent. So why not add prefixes for these problems? Will others outside of movement disorders use a system that focuses only on movement?

Historically, the traditional locus nomenclature aimed at designating a gene's approximate location in the genome. It was not designed for classification of phenotypes. The new plan attempts to link phenotypes and genotypes. However, there are already better tools for linking phenotypes and genotypes. The new plan will create confusion because nomenclature will be unstable due to subjective and arbitrary phenotype assignments, constant evolution with expanding knowledge, and almost certain disagreement among experts. Also unclear is who will have authority to adjudicate disagreements and render decisions. Before adopting the new plan, we must ask whether it is merely replacing old problems with new ones (Table 1). Instead of fixing the broken locus nomenclature system, perhaps we should put it into our magician's hat, and make it disappear.

\section{Acknowledgments}

All financial disclosures for the past year

H. A. Jinnah has active grant support from the US government (National Institutes of Health), private philanthropic organizations (the Benign Essential Blepharospasm Research Foundation, Cure Dystonia Now), and industry (Merz Inc., Ipsen Inc.). Dr. Jinnah also recently served as a consultant for Psyadon Pharmaceuticals and Medtronic, Inc. Dr. Jinnah serves on the Scientific Advisory Boards for te Cure Dystonia Now, the Dystonia Medical Research Foundation, Lesch-Nyhan Action France, the Lesch-Nyhan Syndrome Children's Research Foundation and Tyler's Hope for a Cure. He also is principle investigator for the Dystonia Coalition, which receives the majority of its support through NIH grant TR001456 from the Office of Rare Diseases Research at the National Center for Advancing Translational Sciences, and NS065701 from the National Institutes of Neurological Disorders and Stroke. The Dystonia Coalition has received additional material or administrative support from industry sponsors (Allergan Inc. and Merz Pharmaceuticals) as well as private foundations (The American Dystonia Society, Beat Dystonia, The Benign Essential Blepharospasm Foundation, Cure Dystonia Now, Dystonia Inc., Dystonia Ireland, The Dystonia Medical Research Foundation, The European Dystonia Federation, The Foundation for Dystonia Research, The National Spasmodic Dysphonia Association, and The National Spasmodic Torticollis Association).

\section{Bibliography}

1. Marras C, Lang A, van de Warrenburg BP, et al. Nomenclature of genetic movement disorders: Recommendations of the international Parkinson and movement disorder society task force. Mov Disord. 2016; 31:436-457. [PubMed: 27079681]

2. Jinnah HA, Visser JE, Harris JC, et al. Delineation of the motor disorder of Lesch-Nyhan disease. Brain. 2006; 129:1201-1217. [PubMed: 16549399]

3. Watts RWE, Spellacy E, Gibbs DA, Allsop J, McKeran RO, Slavin GE. Clinical, post-mortem, biochemical and therapeutic observations on the Lesch-Nyhan syndrome with particular reference to the neurological manifestions. Quart J Med. 1982; 201:43-78.

4. Asmus F, Zimprich A, Tezenas Du Montcel S, et al. Myoclonus-dystonia syndrome: epsilonsarcoglycan mutations and phenotype. Ann Neurol. 2002; 52:489-492. [PubMed: 12325078]

5. Nardocci N, Zorzi G, Barzaghi C, et al. Myoclonus-dystonia syndrome: clinical presentation, disease course, and genetic features in 11 families. Mov Disord. 2008; 23:28-34. [PubMed: 17853490] 


\section{Table 1}

\section{Limitations of old and new genetic locus nomenclature}

\begin{tabular}{|c|c|}
\hline Traditional system & Proposed system \\
\hline Fails to discriminate risk genes from disease genes & Fails to discriminate risk genes from disease genes \\
\hline $\begin{array}{l}\text { Failure of some disorders to be assigned a locus } \\
\text { prefix }\end{array}$ & $\begin{array}{l}\text { Failure of some disorders to be assigned a locus } \\
\text { prefix }\end{array}$ \\
\hline $\begin{array}{l}\text { Unconfirmed link between some locus prefixes and } \\
\text { some disorders }\end{array}$ & $\begin{array}{l}\text { Unconfirmed link between some genes and some } \\
\text { disorders }\end{array}$ \\
\hline $\begin{array}{l}\text { Greatly oversimplifies relationship between } \\
\text { phenotype and gene }\end{array}$ & $\begin{array}{l}\text { Moderately oversimplifies relationship between } \\
\text { phenotype and gene }\end{array}$ \\
\hline $\begin{array}{l}\text { Inconsistent relationship between locus prefix and } \\
\text { implied phenotype }\end{array}$ & $\begin{array}{l}\text { Complex and evolving relationship between locus } \\
\text { prefix and phenotype }\end{array}$ \\
\hline $\begin{array}{l}\text { Erroneous prefix due to improper phenotypic } \\
\text { ascertainment }\end{array}$ & $\begin{array}{l}\text { Arbitrary and incomplete prefixes based only on } \\
\text { movement disorder }\end{array}$ \\
\hline More than one prefix assigned for the same disorder & $\begin{array}{l}\text { Multiple prefixes conferred simultaneously to the } \\
\text { same disorder }\end{array}$ \\
\hline $\begin{array}{l}\text { Prefix assigned without identification of locus or } \\
\text { gene }\end{array}$ & $\begin{array}{l}\text { Prefix assigned based on incomplete knowledge of } \\
\text { phenotype that frequently evolves }\end{array}$ \\
\hline Some phenotypes missing (e.g. tremor) & $\begin{array}{l}\text { Addition of phenotypes will require revision of } \\
\text { substantial numbers of existing assignments }\end{array}$ \\
\hline No clear authority for curating errors & No clear authority for curating errors \\
\hline $\begin{array}{l}\text { No clear authority for adjudicating differences of } \\
\text { opinion }\end{array}$ & $\begin{array}{l}\text { No clear authority for adjudicating differences of } \\
\text { opinion }\end{array}$ \\
\hline $\begin{array}{l}\text { Clinical value limited because of poor } \\
\text { correspondence between prefix and phenotype }\end{array}$ & $\begin{array}{l}\text { Clinical value limited because of confusion created } \\
\text { by arbitrary and changing prefixes }\end{array}$ \\
\hline
\end{tabular}

Mov Disord. Author manuscript; available in PMC 2017 November 01. 